\title{
The holistic way of tackling the COVID-19 pandemic: the one health approach
}

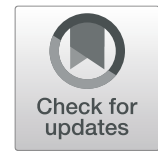

Vivian Mushi[D

\begin{abstract}
The severe acute respiratory syndrome coronavirus 2 (SARS-CoV-2) that is causing a global pandemic had a zoonotic origin in China. Considering the inter-connectedness between human, environment, and animal health, the One Health approach is the appropriate strategy to control and mitigate the effects of the ongoing coronavirus disease 2019 (COVID-19). This letter explains the benefits of the One Health approach and recommends specific measures that could be taken to accelerate the fight against COVID-19 and prevent the spread of newly emerging infectious diseases.
\end{abstract}

Keywords: COVID-19, SARS-CoV-2, One health approach, Adoption and benefits

\section{To the Editor}

The novel severe acute respiratory syndrome coronavirus 2 (SARS-CoV-2) is the etiological agent responsible for a respiratory illness known as coronavirus disease 2019 (COVID-19). The World Health Organization (WHO) declared COVID-19 a public health emergency of international concern on 30 January 2020 and, because of the worldwide spread, a pandemic on 11 March 2020 [1]. Evidence to date from virus genome sequencing and evolutionary analysis suggests that the SARS-CoV-2 originated from bat populations, and thus, transmission to humans was possible either directly from bats to humans or indirectly through an unknown intermediate host $[2,3]$.

Because SARS-CoV-2 has a zoonotic origin, adoption of a One Health approach could be the best mechanism to combat COVID-19. The One Health approach involves multi-sectoral and trans-disciplinary collaborative efforts that work from local, regional, national to global levels to achieve optimal health and well-being of people, animals, and plants in shared environments. Therefore, a One Health approach aims to lower risk and mitigate effects of health crises occurring at the interface between

\section{Correspondence: vmushi31@gmail.com}

Department of Parasitology and Medical Entomology, School of Public

Health and Social Sciences, Muhimbili University of Health and Allied

Sciences, P.O. Box 65001, Dar es Salaam, Tanzania humans, animals, and their environments [4]. The One Health approach is not a new concept. The history goes back to the 1800s, when scientists observed the link between human and animal health especially similarities in disease processes among animals and humans, and the concept was further advanced in the twentieth century due to the threat of emerging pandemics such as the severe acute respiratory syndrome (SARS) and avian influenza (H5N1) [5].

The global community can adopt a One Health approach in the fight against COVID-19 by the following steps. First, conduct an interdisciplinary coordinated surveillance and monitoring during the pandemic with a view to studying the disease patterns and trends, intensity of transmission, geographical spread, and impact of the pandemic for modification of the existing response strategies. Second, establish integrated human and animal health laboratories that will help to strengthen the capacity to conduct integrated studies on COVID-19. Third, collaborate and share protocols, ideas, and guidelines on COVID-19 diagnosis, interpretation of results, a reporting system, and data sharing. This will ensure that the same standards are observed worldwide for diagnosis, reporting, and results sharing. Fourth, governments should coordinate multi-sectoral engagement and partnership with One Health stakeholders in the fight

(c) The Author(s). 2020 Open Access This article is licensed under a Creative Commons Attribution 4.0 International License, which permits use, sharing, adaptation, distribution and reproduction in any medium or format, as long as you give appropriate credit to the original author(s) and the source, provide a link to the Creative Commons licence, and indicate if changes were made. The images or other third party material in this article are included in the article's Creative Commons licence, unless indicated otherwise in a credit line to the material. If material is not included in the article's Creative Commons licence and your intended use is not permitted by statutory regulation or exceeds the permitted use, you will need to obtain permission directly from the copyright holder. To view a copy of this licence, visit http://creativecommons.org/licenses/by/4.0/. 
against COVID-19 so as to speed up prevention and disease response $[4,6,7]$.

A One Health approach will be beneficial as we fight against COVID-19 in financially constrained settings as it allows cost-sharing in an interdisciplinary field within the responsible ministries. Human and animal health sectors working separately are more costly than when the sectors work collaboratively and share resources [8]. One Health laboratories are crucial for conducting research in order to collect and share data and advance knowledge that will help to reduce ambiguity in COVID-19 mitigation decisions [9]. The One Health approach, through the collaboration of multiple sectors, will help in controlling the disease and will lessen the social and economic impact of the COVID-19 pandemic [10]. The lessons learned from utilizing the One Health approach in the pandemic will be useful for risk reduction and control of emerging and re-emerging infectious diseases.

The current COVID-19 pandemic is an opportune time to emphasize the One Health approach in global health. I wish to recommend the following measures to accelerate the fight against COVID-19. These are to:

i. Mobilize resources that will assist in the implementation of the One Health activities such as surveillance and monitoring of the COVID-19 pandemic; and

ii. Involve communities in the fight against COVID19. Implementation of the One Health approach without the active involvement of communities will not succeed because an understanding of community knowledge, practices, and customs are fundamental for COVID-19 prevention and control interventions targeting those communities.

In conclusion, although COVID-19 has already spread in many parts of the world, implementing the One Health approach could be the solution to the control of COVID-19. Now more than ever, it is time to adopt, invest in, and embrace the One Health approach because it can help with both the current COVID-19 pandemic and also mitigate the effects of other emerging infectious diseases.

\section{Abbreviations}

COVID-19: Coronavirus disease 2019; SARS-CoV-2: Severe acute respiratory syndrome coronavirus 2; WHO: World Health Organization

\section{Acknowledgements}

The author wishes to thank Debbie Bain Brickley and Joanne Power for the English revision and editing of this manuscript.

\section{Author's contributions}

VM is the sole contributor to this article. The author read and approved the final letter.
Funding

No external funding was used in the preparation of this letter.

Availability of data and materials

All the data used are from the references provided.

Ethics approval and consent to participate

Not applicable.

Consent for publication

Not applicable.

\section{Competing interests}

There are no competing interests.

Received: 25 June 2020 Accepted: 6 August 2020

Published online: 14 August 2020

\section{References}

1. Coronavirus -19 events as they happen. https://www.who.int/ emergencies/diseases/novel-coronavirus-2019/events-as-they-happen. Accessed 19 June 2020

2. Yoo HS, Yoo D. COVID-19 and veterinarians for one health, zoonotic- and reverse-zoonotic transmissions. J Vet Sci. 2020;21(3):e51. https://doi.org/10. 4142/jvs.2020.21

3. Guo YR, Cao QD, Hong ZS, et al. The origin, transmission and clinical therapies on coronavirus disease 2019 (COVID-19) outbreak - an update on the status. Mil Med Res. 2020;7(1):11. https://doi.org/10.1186/s40779020-00240-0.

4. Killewo J, Mdegela R. OHCEA Tanzania Dar Es Salaam Morogoro Tanzania: one health training manual lecture notes and materials; 2018.

5. Mackenzie JS, Jeggo M. The one health approach-why is it so important? Trop Med Infect Dis. 2019:4(2):88. https://doi.org/10.3390/ tropicalmed4020088.

6. WHO guidance for surveillance during an influenza pandemic. https:// www.who.int/influenza/preparedness/pandemic/WHO_Guidance_for_ surveillance_during_an_influenza_pandemic_082017.pdf. Accessed 19 June 2020.

7. USAID-Emerging Pandemic Threats. https://www.cbd.int/health/onehealthcasestudies2016-final-en.pdf. Accessed 20 June 2020.

8. Häsler B, Gilbert W, Jones BA, Pfeiffer DU, Rushton J, Otte MJ. The economic value of one health in relation to the mitigation of zoonotic disease risks. Curr Top Microbiol Immunol. 2013;365:127-51. https://doi. org/10.1007/82_2012_239.

9. Häsler B, Cornelsen L, Bennani H, Rushton J. A review of the metrics for one health benefits. Rev Sci Tech. 2014;33(2):453-64. https://doi.org/10. 20506/rst.33.2.2294

10. Bonilla-Aldana DK, Dhama K, Rodriguez-Morales AJ. Revisiting the one health approach in the context of COVID-19: a look into the ecology of this emerging disease. Adv Anim Vet Sci 2020: 8(3): 234-237. https:/doi.org/ https://doi.org/10.17582/journal.aavs/2020/8.3.234.

\section{Publisher's Note}

Springer Nature remains neutral with regard to jurisdictional claims in published maps and institutional affiliations.
Ready to submit your research? Choose BMC and benefit from:
- fast, convenient online submission
- thorough peer review by experienced researchers in your field
- rapid publication on acceptance
- support for research data, including large and complex data types
- gold Open Access which fosters wider collaboration and increased citations
- maximum visibility for your research: over $100 \mathrm{M}$ website views per year
At $B M C$, research is always in progress.
Learn more biomedcentral.com/submissions 